\title{
Dermatosis localizada en un perro de 2 años
}

\author{
Galan Torres JA. ${ }^{1}$, Ortega García M ${ }^{\mathrm{a}} \mathrm{V}^{2}$
}

Sanid. mil. 2011; 67 (2): 129-130; ISSN: 1887-8571

Perro Setter de 2 años que presenta una lesión confinada a la cabeza, con presencia de placas eritematosa, depiladas, costrosas y descamadas, acompañadas de prurito. Se realiza biopsia de las lesiones para su estudio histopatológico.
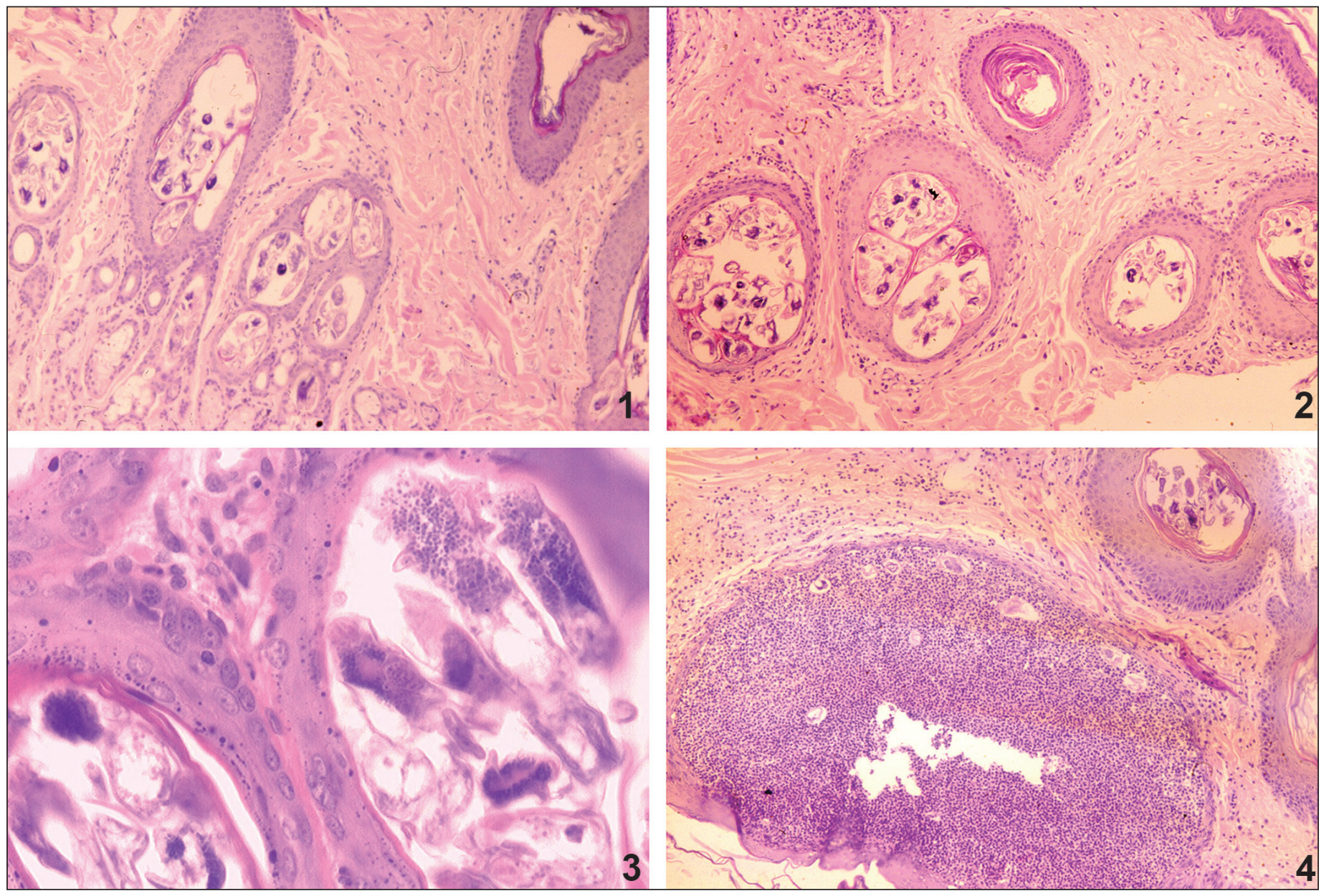

Figura 1. Folículos pilosos dilatados en los que se aprecian corpúsculos fusiformes, densos y desigualmente teñidos, sin presencia de bulbos pilosos. H-E. 100x.

Figura 2. Moderado infiltrado inflamatorio perifolicular de células linfoides.En el ángulo superior derecho se muestra la epidermis. H-E. 100x. Figura 3. Los parásitos intrafoliculares. En el margen superior derecho se aprecia un parásito casi completo. H-E. 400x.

Figura 4. Foliculitis-forunculosis. Masas de PMN neutrófilos en un piogranuloma debido a la ruptura de un folículo. Se observa la presencia de parásitos. H-E. $100 x$.

${ }^{1}$ Tcol. Veterinario. Centro Militar de Veterinaria. Servicio de Microbiología, Higiene y Sanidad Ambiental. Madrid. España.

${ }^{2}$ Tte. Veterinaria. Escuela Militar de Sanidad.

Dirección para correspondencia: Centro Militar de Veterinaria de la Defensa. Servicio de Microbiología, Higiene y Sanidad Ambiental. C/ Darío Gazapo, 3. 28024 Madrid.

Recibido: 25 de febrero de 2010

Aceptado: 6 de abril de 2010 


\section{Diagnóstico: Demodicosis localizada}

En las imágenes histológicas se pueden observar folículos pilosos dilatados, rellenos de ácaros y material queratinoso, así como un número variable de tipos de células inflamatorias (Figs. 1 y 2). Existe también una reacción piogranulomatosa (Fig. 3).

El ácaro Demodex canis parasita los folículos pilosos de la piel y provoca frecuentemente lesiones faciales en perros jóvenes. Estas lesiones consisten en alopecias localizadas, con eritema y descamación, y suelen ir acompañadas de infección bacteriana secundaria ${ }^{1}$. El diagnostico puede realizarse directamente mediante raspado profundo de las lesiones.

Si los ácaros son numerosos y la respuesta celular es mínima o los eosinófilos están ausentes, especialmente cuando existe forunculosis, el perro demuestra tener un severo estado de inmunosupresión ${ }^{2}$.

Los perros con demodicosis presentan una respuesta cutánea local que se incrementa con la severidad de la enfermedad clínica ${ }^{3}$.

\section{Tratamiento}

No se recomienda el tratamiento con insecticidas ya que la mayoría de los casos se resuelven espontáneamente en 6 u 8 se- manas; esta fue la evolución del caso presentado. Solo un $10 \%$ aproximadamente de las sarnas demodécicas localizadas se convierten en generalizadas, incluso a pesar del tratamiento con ami$\operatorname{traz}^{1,2}$.

Los corticoides están totalmente contraindicados. Para controlar el prurito se deben utilizar antihistamínicos y/o ácidos grasos omega-3/omega-6.

Para la demodicosis generalizada también se está empleando actualmente ivermectina y milbemicina, con buenos resultados.

\section{BIBLIOGRAFÍA}

1. Saló E. Manual clínico de dermatología en el perro y el gato. Pulso ediciones. 1997; 167-168.

2. Scott DV, Muller GH, Griffin CE. Small animal dermatology. 6th Edition. 2000; 457-474.

3. Day MJ. An immunohistochemical study of the lesions of demodicosis in the dog. J Comp Path 116. 1997; 203. 